\title{
Effects of Heat Exposure Duration on Saliva Traces on Cigarette butts as Forensic Identification Tools
}

\author{
Mely Purnadianti ${ }^{1}$, Andika Aliviameita ${ }^{2}$, Diah Ayu Nur Rochmawati ${ }^{3}$, Dian Amanovitasari ${ }^{4}$ \\ Ilmu Forensik Sekolah Pasca Sarjana Universitas Airlangga Surabaya Jawa Timur
}

Correspondence: Mely Purnadianti, Magister Ilmu Forensik, Sekolah Pascasarjana, Universitas Airlangga Surabaya, Jl. Airlangga 4-6, Surabaya, email : omansukarna@gmail.com, telpon : +6282136634060

\begin{abstract}
Identification processes are not only conducted on the dead bodies of criminal victims, but also on the evidence found at the location. The length of time between the crimes happening and the investigation of the evidence is a problem in relation to the blood group identification process through saliva traces on cigarette butts. Wet saliva usually becomes trace in an hour and 40 minutes at room temperature, and up to less than 3 hours if there any influencing factors. The purpose of this research is to analyse the effects of heat exposure duration on the protein content of the saliva traces on cigarette butts in order to help the forensic blood group identification process. A time series design was used in this research in which 18 cigarette butts were collected from 6 individuals of blood groups $\mathrm{A}, \mathrm{B}$, and $\mathrm{AB}$. The samples were then incubated for 1.3 and 6 hours respectively. The protein content was determined using a trizol reagent and Spectrophotometer UV. Statistical analysis using a T-test was conducted to analyse the results. There was a decrease in the protein content of the saliva trace samples at the time points of 1,3 and 6 hours. The protein content of the saliva could still be detected at the time points of 1,3 and 6 hours. These findings suggest that the protein analysis of saliva trace samples on cigarette butts can be used in the forensic blood group identification process.
\end{abstract}

Keywords: Cigarette butts, Saliva traces, Protein, Forensic identification

\section{Introduction}

Forensic identification is the methods undertaken by investigators to investigate the identity of the victims and culprits. The identification processes are not only conducted on the dead body of criminal victims, but also on the evidence found at the location (Gani, 2002). In the murder case that happened on 14th May 2013 in Bangkingan Madura, East Java, several items of information like the smoking habits, brand, lip print, finger print and even saliva traces can be detected on the cigarette butt as evidence found (Hardjanto Pudji, 2015). The saliva traces can be used as a specimen in blood group identification which is a secondary identification component (Rogers et al, 2005). The glicoprotein content in saliva is a component used to determine blood group in the $\mathrm{ABO}$ and Lewis system in individuals who have a secretor blood group (Albertolle et al, 2017). A research study conducted at a State Police Laboratory in Jakarta found that $75 \%$ of police officers have a secretor blood group. On the other hand, $85 \%$ of the world's population have a nonsecretor blood group.

The length of time between crimes happening and the investigation of the evidence is a problem in the blood group identification process through the saliva traces on cigarette butts. Wet saliva usually become trace in an hour and 40 minutes at room temperature, and up to less than 3 hours if there any influencing factors (Jellinghaus et al, 2015). Early blood group identification through saliva samples on cigarette butt evidence needs to be conducted in order to help investigate the identity of the victims and culprits. The aim of this study is to determine the time span for blood group analysis through saliva trace samples down to the remaining protein levels.

\section{Method}

This study was a laboratory experiment using a time series design which used 1, 3 and 6 hours at room temperature as the respective intervals. The samples used in this study consisted of 18 cigarette butts. In this study, the saliva on the cigarette butts was set up as the independent variable, while the dependent variable was the identification of the forensic blood type. The control variable in this study was the time duration used by the researchers that ranged between 1 hour, 3 hours and 6 hours to determine the decreasing protein count in saliva. The confounding variable was the temperature because it can lead to the saliva drying on the cigarette butts. This study was conducted in the TDC (Tropical Disease Centre) Laboratory at the Tropical Disease Centre Institute of Airlangga University, Surabaya and the forensic laboratory of Saiful Anwar Public Hospital, in Malang. A non-parametric statistic test (normality test, homogeneity, $\mathrm{t}$ test) with linear regression analysis was used to determine the influence of the exposure time to the temperature with the amount of the protein level in the saliva on the cigarette butt.

\section{Results and Discussion}

The samples were obtained from six cigarette butts smoked by six individual research 
subjects who know their blood type. The cigarette butt with sample number 1 (A1 - F1) was swabbed one hour after being smoked; the cigarette butt with sample number 2 (A2 - F2) was swabbed three hours after being smoked; the cigarette butt with sample number 3 (A3 - F3) was swabbed six hours after being smoked. The estimation of the protein level in saliva was done using a Spektrophotometer using a $280 \mathrm{~nm}$ wavelength, which used an absorbance ratio of $280 / 260$ to determine the correction factor that exists in the table. The protein level is determined by the following formula: protein level $(\mathrm{mg} / \mathrm{ml})=\mathrm{A} 280 \mathrm{x}$ correction factor $\mathrm{x}$ dilution.

Table 6. Average protein level

\begin{tabular}{|c|c|c|}
\hline No & $\begin{array}{l}\text { Exposure duration at } \\
\text { room temperature } \\
\text { (hours) }\end{array}$ & $\begin{array}{l}\text { Mean protein } \\
\text { content }(\mathrm{mg} / \mathrm{ml})\end{array}$ \\
\hline 1 & 1 & 1,43 \\
\hline 2 & 3 & 1,49 \\
\hline 3 & 6 & 1,86 \\
\hline
\end{tabular}

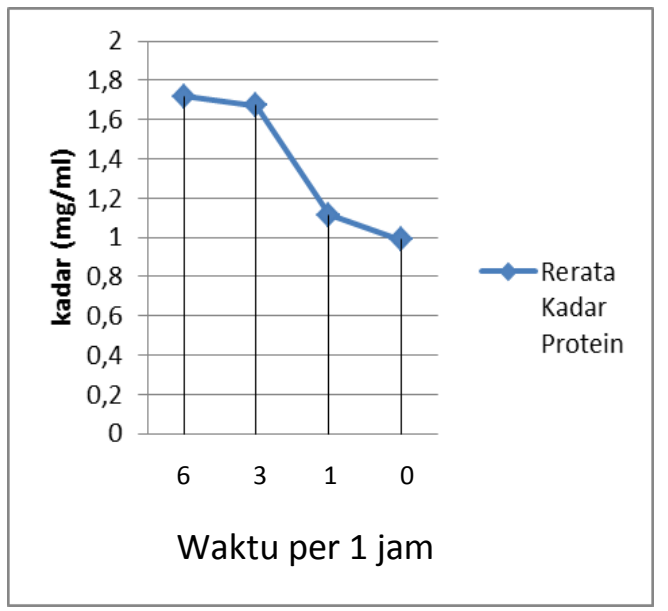

Figure 1. Curve of Average Protein Level Exposure Duration at Room Temperature

The protein level of the cigarette butts in Table 6 shows that after one hour post-smoke, the swab ranged from $0.686 \mathrm{mg} / \mathrm{ml}$ to $2,958 \mathrm{mg} / \mathrm{ml}$, after 3 hours post-smoke the swab ranged from $1.355 \mathrm{mg} / \mathrm{ml}$ to $1.818 \mathrm{mg} / \mathrm{ml}$, and after 1 hour postsmoke the swab ranged from $0.564 \mathrm{mg} / \mathrm{ml}$ to 1.839 $\mathrm{mg} / \mathrm{ml}$. This was influenced by the saliva spotted surface area of the subjects on the cigarette butts and the salivary degree due to hydration. The greater surface area of the salivary spots and its corresponding hydration level, the greater the salivary protein that is obtained. Table 6 shows the average protein level at each swab time interval on the cigarette butt. The data shows a decreasing protein level over the exposure duration at room temperature. Figure 1 shows the decreasing curve of the protein level. There was a significant decrease in the protein level of the 3rd swab compared to the 6th swab.

The protein level data of each exposure time group had a normal distribution with a significance value of $>0.05$. In the homogeneity test using a $\mathrm{T}$ test, the significance value was 0.086 (>0.05), which means that there were at least two groups where there was no significant difference in the protein level. In the Post Hoc test, the homogeneity test was performed between the groups of exposure time; a significant difference was found between the group with 1 hour of exposure time and the 6 hour group with a significance value of 0,038 $(<0,05)$. The other tests do not show a significant difference with a significance value of $>0.05$. The correlation test between exposure time at room temperature and the protein levels using a Pearson correlation test, shows a significance value of 0.013 $(<0.05)$. This means that there is significant correlation between exposure time at room temperature and salivary protein levels. The correlation value is -0.499 , indicating that the longer the exposure time, the smaller the level of salivary protein. The correlation strength is moderate.

\section{Conclusion}

The exposure time at room temperature has been shown to influence the levels of protein in the saliva on cigarette butts. There is a decreasing level of protein in the salivary swab at 1 hour, 3 hours and 6 hours after being smoked with an average level $1.717969 \mathrm{mg} / \mathrm{ml}, 1.673408 \mathrm{mg} / \mathrm{ml}, 1.113023$ $\mathrm{mg} / \mathrm{ml}$, and $0.988335 \mathrm{mg} / \mathrm{ml}$ respectively. Statistically, there is a significant correlation between the duration of the exposure time at room temperature with salivary protein level. Moreover, the correlation value shows that the longer the exposure time, the smaller the level of salivary protein, The correlation strength is moderate. The mean value of the protein content of the salivary swab 1 hour after bite with the salivary swab 6 hours after bite was also obtained.

\section{Reference}

Afifah, Ratna, Nurul. Pretrial And Scope, Akademika Pressindo, Jakarta, 1986.

Albertolle, Matthew E; Hassis, Maria E; Ng, Connie Jen; Et Al. Mass SpectrometryBased Analyzes Showing The Effects Of Secretor And Blood Group Status On Salivary N-Glycosylation. Clinical Proteomics Journal.2015. [Retrieved January 2017.]

Alfanie Iwan, Nirmalasari Nila, Arizal Hendi Muhammad. Forensic and Medicolegal Medical Sciences. Jakarta: Rajawali Pers, 2017. 
Asthia T. Comparative Study of Blood Type Examination Result on Saliva Sample Immediately and Saliva is stored for 1 hour at Temperature $15^{\circ}$ C. Thesis. Universityof Indonesia. Jakarta, 2007.

De Almeida, Et Al. Saliva Composition And Functions: A Comprehensive Review. The Journal Of Contemporary Dental Practice.2008. [Accessed January 2017.]

Fawles, J et al. The Chemical Constituent In Cigarettes And Cigarette Smoke. New Zealand: New Zealand Ministry Of Health. 2000. [Retrieved February 2017.]

Gani. Forensic Medicine. Faculty of Medicine Andalas University. Padang, 2002

Gerard J. Tortora, Bryan Derrickson. Principles of Anatomy And Physiology 912th Edition. USA; John Wiley And Sons, Inc. 2009. [Retrieved January 2017.]

Guyton and Hall. Book of Medical Physiology Edition 11. Jakarta: EGC, 2008

Hardjanto Pudji. TK Talk. Surabaya: PT. Refka Petra Media, 2015.

Haque, amdadul M; Adhikari, Benu. Drying and Denaturations of proteins in spray drying process. Handbook of industrial drying. Taylor and francis Group, LLC, 2015. [Accessed January 2017.]

Hold. K.M, Boer. D, Juidema. J. Saliva as an analytical tool in Toxicology. International Journal of drug testing. P: 135, 1999 [Accessed February 2017]

Idries. The Application of Forensic Medicine in the Investigation Process. Jakarta: Sagung Seto, 2008.

Jellinghaus K, Blasser L, Scheller C Bohnert M. Drying time for Human Saliva. Arch Criminal Mart-Apr; 235 (3-4): 99-109. $2015 . \quad$ https: //www.ncbi.nlm.nih.gof/pubmed/2641908 4. [Accessed February 2017.]

Joachim Klimek. Saliva and Oral Health. Lecture Handout for Undergraduate Student of Dentistry. 2004 Germany: 4-37

Leffondre et al. Modeling Smoking History. American Journal of Epidemilogy, 2002. Http://aj.oxford.journal.org/contant/156/9/ 813.full.pdf. [Accessed February 2017]

Martiman Prodjohamidjojo. Comment on Criminal Procedure Code: Criminal Procedure Code, Jakarta: Pradnya Paramitha, 2009.

Michael Bowers and Gary Bell. Journal Of Indian Academy of Oral Medicine And Radiology, July-September 2011, 1995. [Accessed February 2017.]

Tery Martin. Harmful Chemicals in Cigarettes. Journal of smoking effect, 2012. Http // quitsmoking.about.com . [Discounted to february 2017.] 